\title{
CONFLICTOLOGICAL CULTURE OF PERSONALITY IN A PROFESSIONAL ENVIRONMENT (BY THE EXAMPLE OF PEDAGOGUES AND ENGINEERS)
}

\author{
Olga Scherbakova \\ The Plechanov Economic University, Moscow, Russia \\ Anna Tatarinceva \\ The Baltic International Academy, Latvia
}

\begin{abstract}
The levels of conflictological culture of pedagogues and engineers, the peculiarities of its formation as well as the comparison of the conflictological culture's levels among representatives of these specialties on the base of their gender and work experience are analyzed in the proposed research. Each specialist owns a certain level of the conflictological culture's development and he/she expresses it in a professional environment. The relevance of the research's theme is caused by the necessity to improve conflictological culture of specialists for their further successful activities. The Aim of the research is the identification of differences in the levels' formation of specialists' conflictological culture by the example of pedagogues and engineers and the influence of such a characteristic as a gender and work experience on it. The Object of the research is the process of forming conflictological culture of pedagogues and engineers. The Methods of the research are the following: 1. the theoretical analysis of scientific literature on the given problem; 2. the empirical analysis of obtained data reflected the level's formation of pedagogues and engineers.
\end{abstract}

Keywords: avoidance, behaviour, communication, conflict, culture, engineer, experience, pedagogue, perception, personality, problem, responsibility, sense, solving, specialist.

\section{Introduction}

The Novelty of the proposed research is in the fact that the authors of the proposed research investigate the conflictological culture's level of specialists (pedagogues and engineers) who already work, but the authors of the previous research investigated only future specialists, students.

The Hypothesis of the research is the following; the significant differences exist in the conflictological culture's formation of representatives of different specialties, exactly of pedagogues and engineers. The additional Hypothesis is that the gender factor influences on the development level of conflictological culture's components.

Conflictological culture of personality is the complex integrative substance included culture of value-semantic sphere of personality, thinking culture, 
culture of senses, communication culture, behavioural culture ensured constructive problem-solving under a conflict (Scherbakova \& Verbicky, 2016).

Culture of value-semantic sphere of personality is a set of existenial and humanistic values of personalities stipulated a personal sense of constructive behaviour of personality under a conflict, positive perception of Self and others (Burton \& Dukes, 1990) which is based on such values as responsibility, freedom, autonomous thinking, and each person takes responsibility for his life and all events in it.

Thinking culture is the ability to analyze rationally a conflict situation on the base of obtained certain knowledge and skills, define the essence of a problem, separate the important things from the secondary ones, come to conclusions, use them in own behaviour (Zaida, 2011). Culture of senses is the ability to realize a constructive and desstructive characters of own experiences, emotions and control them (Coser, 1993). Behavioral conflictological culture is the ability to act and solve problems in such a way that can allow to avoid a conflict or to control it at all stages (Burton \& Dukes, 1990). Communicative culture is the ability to express own feelings and emotions adequately and implement willingness to a dialogue (Самсонова, 2002)).

\section{The Method of the Empirical Stage of the Research}

Participants. The sample of the empirical stage of the research was the following: 60 pedagogues (there were 45 women and 15 men) and 60 engineers (there were 10 women and 50 men) were selected for the given investigation.

Their work experience was in the range from 1 year to 15 years. The age of the respondents was in the range from 23 till 68. Instruments. In order to determine the level of conflictological culture formation of pedagogues and engineers the authors of the research conducted the empirical research on the base of the Procedure „The method of personality's conflictological culture investigation" elaborated by Scherbakova (Scherbakova \& Chaikina, 2009). The level of conflictological culture formation can be determined only by taking into account the level of the development of all components of conflictological culture of personality. Each level of development was defined according to the following criteria:

Table 1 The determination of the component development level of conflictological culture of personality according to the sum of points (score) in a scale

\begin{tabular}{|c|c|}
\hline Score on a scale & The level on a scale \\
\hline$[3-11]$ & low \\
\hline$[12-17]$ & average \\
\hline$[18-21]$ & high \\
\hline
\end{tabular}


According to Scherbakova (2011) conflictological culture of a specialist has been formed if it is on the high level of development, and it has not been formed if it is on the average or low level of development.

\section{Results}

The results of the investigation of the conflictological culture level formation of all participants of the research (pedagogues anf ingeneers) are shown in the Figure 1.

The levels of conflictological culture of specialists

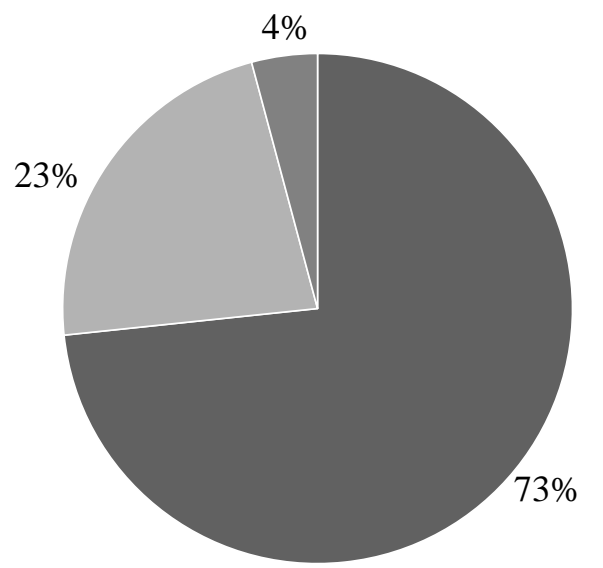

- The Low formation level

- The Middle formation level

The High formation level

Figure 1 The formation levels of respondents' conflictological culture

As it isseen from the Figure 1,73\% of respondents have the low level of conflictological culture formation; $23 \%$ of respondents have the average level of conflictological culture formation; and only $4 \%$ of respondents have the high level of conflictological level formation.

The next Figure 2 reflects the level of conflictological culture formation of specialists in both samples.

As it is seen from the Figure 2, the level of conflictological culture is formed only of $27 \%$ of respondents inboth groups (pedagogues and engineers), and not formed at all of $73 \%$ of them. The authors conducted the empirical analysis of the obtained data of specialists' conflictological culture's components.

The authors used the following abbreviations: the abbreviation CC- means communicative culture; TC - means thinking culture, BC-means behavioural culture; CS-means culture of senses. 
The percentage of conflictological culture formation level

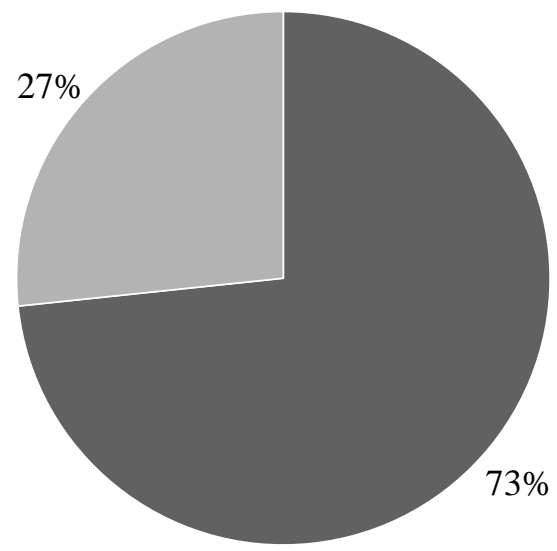

- Is'not formed

Is formed

Figure 2 The level of conflictological culture formation of specialists in both samples (pedagogues and engineers)

Table 2 The research results of two independent samples (pedagogues and engineers)by the help of the Student's t-test and the Levene'st-test)

\begin{tabular}{|c|c|c|c|c|c|c|c|c|}
\hline & \multirow{3}{*}{$\begin{array}{l}\text { The Levene's } \\
\text { t-criterion of } \\
\text { dispersions } \\
\text { 'equality } \\
\text { Significance }\end{array}$} & \multicolumn{6}{|c|}{ The Levene's t-criterion for equality of means } \\
\hline & & & \multirow[t]{2}{*}{$\mathrm{t}$} & \multirow[t]{2}{*}{ st.sv } & \multirow[t]{2}{*}{ Meanings } & \multirow[t]{2}{*}{$\begin{array}{l}\text { The } \\
\text { average } \\
\text { differe } \\
\text { nce }\end{array}$} & \multicolumn{2}{|c|}{$\begin{array}{c}\text { The confidence } \\
\text { interval for } \\
\text { differences is } \\
95 \%\end{array}$} \\
\hline & & & & & & & low & high \\
\hline \multirow{2}{*}{$\mathrm{CC}$} & $\begin{array}{l}\text { Equal dispersion } \\
\text { are supposed }\end{array}$ & \multirow[t]{2}{*}{0,026} & $-2,5$ & 118 & 0,012 & $-1,95$ & $-3,47$ & $-0,43$ \\
\hline & $\begin{array}{l}\text { Equal } \\
\text { dispersions are } \\
\text { not supposed }\end{array}$ & & $-2,5$ & 107,189 & 0,013 & $-1,95$ & $-3,472$ & 0,428 \\
\hline \multirow[t]{2}{*}{$\mathrm{TC}$} & $\begin{array}{l}\text { Equal dispersions } \\
\text { are supposed }\end{array}$ & \multirow[t]{2}{*}{0,663} & $-2,2$ & 118 & 0,03 & $-1,383$ & $-2,632$ & 0,134 \\
\hline & $\begin{array}{l}\text { Equal dispersions } \\
\text { are not supposed }\end{array}$ & & $-2,2$ & 116,801 & 0,03 & $-1,383$ & $-2,633$ & 0,134 \\
\hline \multirow{2}{*}{$\mathrm{BC}$} & $\begin{array}{l}\text { Equaldispersions } \\
\text { are supposed }\end{array}$ & \multirow[t]{2}{*}{0,306} & $-1,8$ & 118 & 0,076 & $-1,45$ & $-3,057$ & 0,157 \\
\hline & $\begin{array}{l}\text { Equal dispersions } \\
\text { are supposed }\end{array}$ & & $-1,8$ & 115,761 & 0,077 & $-1,45$ & $-3,057$ & 0,157 \\
\hline \multirow{2}{*}{$\mathrm{CS}$} & $\begin{array}{l}\text { Equal dispersions } \\
\text { are supposed }\end{array}$ & \multirow[t]{2}{*}{0,176} & $-0,7$ & 118 & 0,492 & $-0,533$ & $-2,066$ & 0,999 \\
\hline & $\begin{array}{l}\text { Equal dispersions } \\
\text { are not supposed }\end{array}$ & & $-0,7$ & 114,279 & 0,492 & $-0,533$ & $-2,067$ & 1 \\
\hline
\end{tabular}


As the significance of the Leven criterion of dispersions'equality on the scale CC is less than. 05 (it means that dispersions differ) the usage of the Student's t-test for the analysis of this scale is illegitimately. That is why the authors of the research used the U-criterion of Mann-Whitney test for the analysis of the samples' difference on the scale CC. Thus, according to the analysis results of the given samples (pedagogues and engineers) by the help of the Student's t-test used for the scales TC, BC, CS, and the U-criterion MannWhitney test used for the scale CC the authors can conclude the following: engineers and pedagogues have significant differences in such components of personality's conflictological culture as thinking culture (the level of significance is equal to .030) and communicative culture (the level of significance is equal to .032). Pedagogues have the higher level of these components than engineers have.

The authors of the research also analyzed the differences in personality's conflictological culture according to respondents' gender. That was done by using the Pearson's criterion. Men have the majority in the profession of an engineer, but women predominate in a teacher's profession. The Figure 4 shows the differences in scales CC, TC, KP, CS according to respondents' genders.

\section{The score-gender based in scales CC, TC, BC, CS}

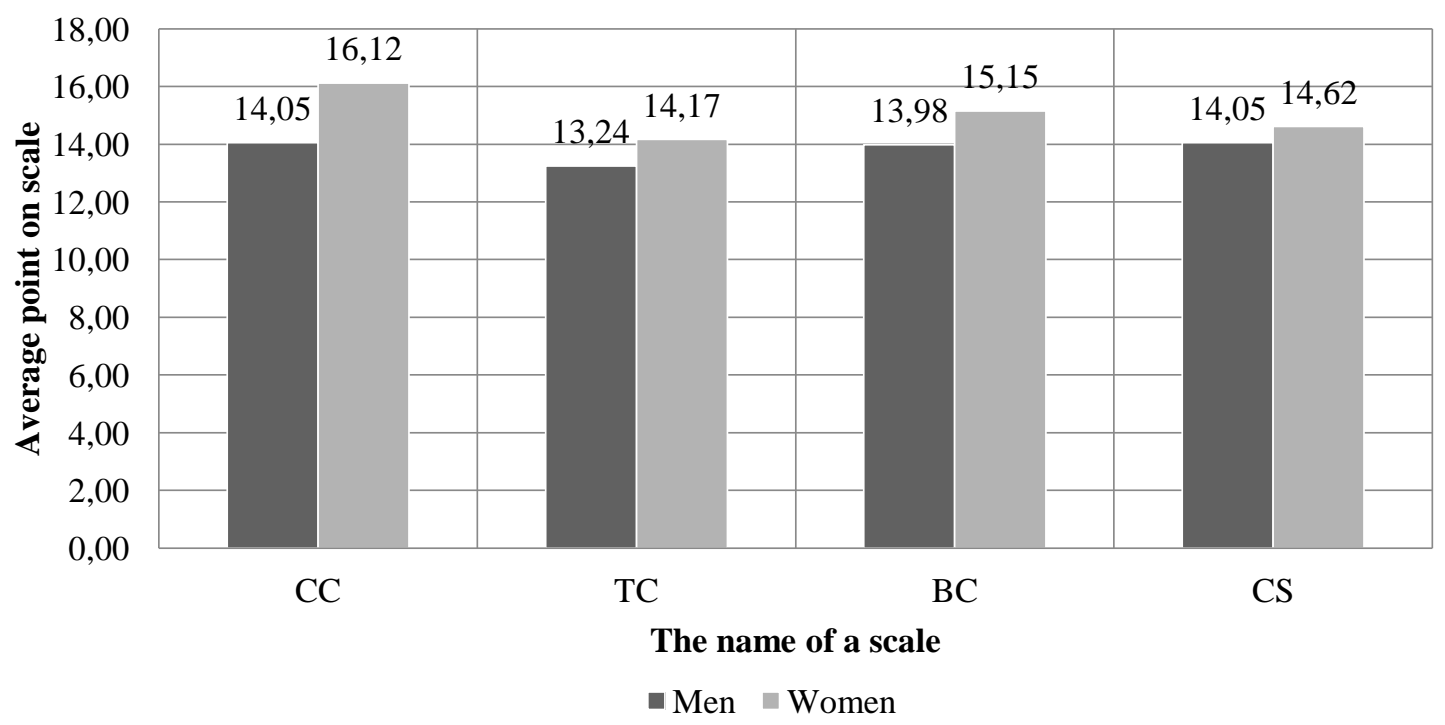

Figure 4 The comparison of the average score between men and women in scales CC, TC, BC, CS

The obtained data show that there are significant differences between men and women in the components' formation level of personality's conflictological 
culture only in the component of communicative culture (CC), the level of significance is equal to .011. The formation level of women is higher than men.

The authors of the research believe that revealed statistically significant differences in the formation level of such components of personality's conflictological culture as communicative culture and thinking culture between engineers and pedagogues could be explained by the specific of pedagogical profession, the necessity to determine clearly a thought, to communicate with students, solve different problems, avoid conflicts.

The results of the interrelations among the age and work experience with the development level of conflictological culture of a specialist is represented in the

\section{The representation of conflictological culture components' correlation}

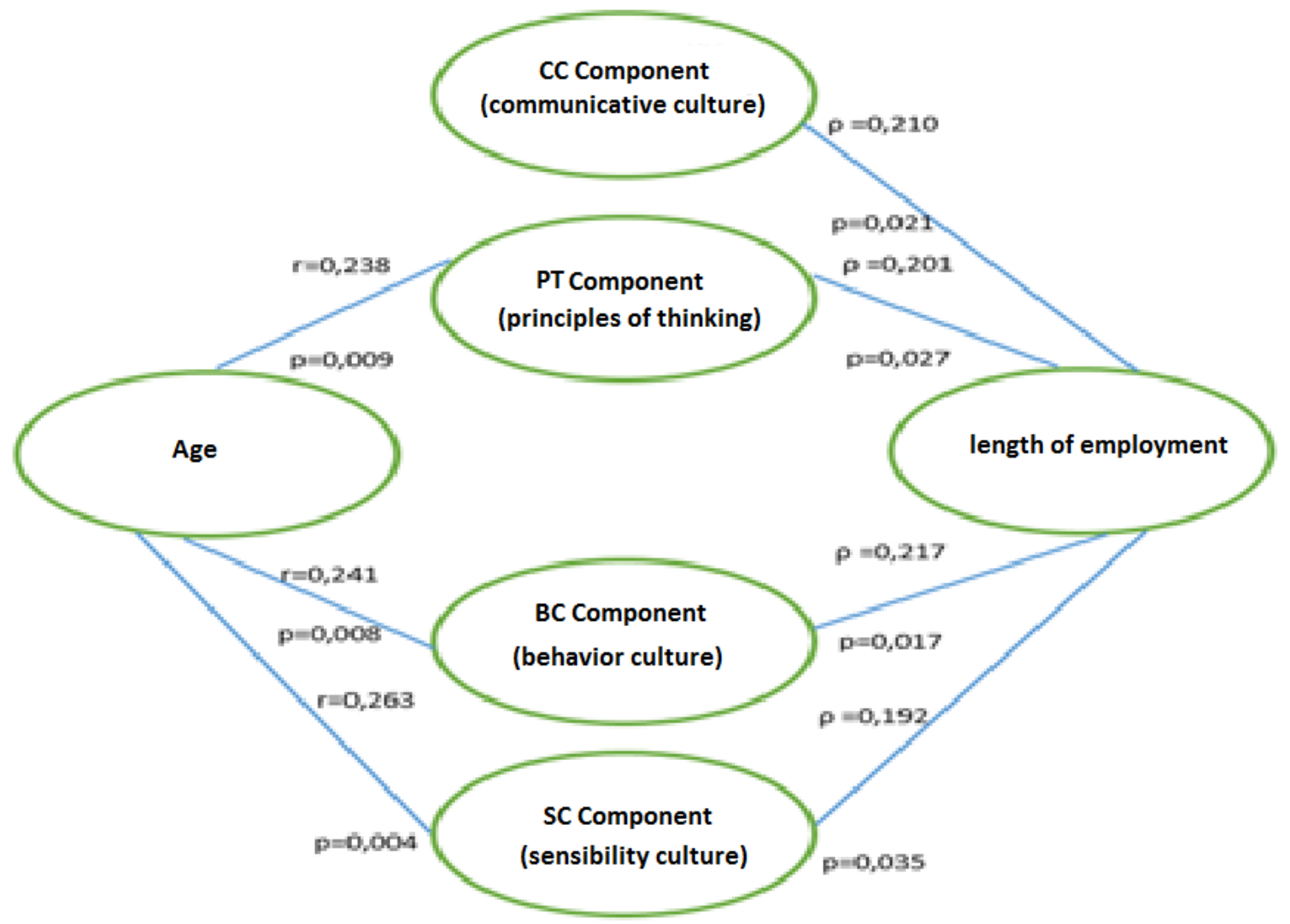

Figure 5 The correlation among components of a specialist's conflictological culture and his/her age; as well as the correlation among components of conflictological culture and a specialist's work experience in a specialty

A very weak correlation among each of the conflictological culture's components with the age of respondents and their work experience allows the 
authors to conclude that the development level of conflictological culture does not depend on age as well as on work experience of a specialist.

\section{Conclusion}

The authors of the proposed research conclude that:

1) the hypothesis that a chosen profession of respondents influences on the formation level of conflictological culture was confirmed, but the additional hypothesis that a respondent's gender influences on the components of conflictological culture was partly confirmed;

2) as the formation level of conflictological culture is not formed of the majority pedagogues and engineers, they should develop further their conflictological culture for their professional productive activities for avoiding or solving problems in conflicts.

\section{References}

Burton, J., \& Dukes, F. (1990). Conflict: Practice in management, settlement and resolution. London: Macmillan.

Coser, L. (1993). Conflict: Social Aspects. NY: Del.

Scherbakova, O., \& Verbicky, A. (2016). Conflictological Culture of Specialists: Technologies of Forming. Moscow: MSPU.

Scherbakova, O., \& Chaikina, E. (2009). Workshop on Conflictology. Moscow: Triada.

Zaida, M. (2011). Models of Effective Communication. London: Cassell.

Самсонова, Н. (2002). Конфликтологическая культура спещиалиста и технология ее формирования в системе вузовского образования. (A specialist's conflictological culture and the technology of its for mingin the system of higher education). Монография. Калининград: КГУ.

Щербакова, О. (2011). Психология конфликтологической культуры личности спеицилиста: формирование в контекстной образовательной среде. (Psychology of a specialist's conflictological culture: its for mingin a contextual educational environment). Москва: ГОУ ВПО «МГТУ им. М. А. Шолохова». 